\title{
Original
}

\section{Long-term Storage of Blood at Freezing Temperatures for Methemoglobin Determination : Comparison of Storage with and without a Cryoprotectant}

\author{
Yasuhiro Ishiwata, Yoshiko Arima, Masaya FujISHIRo, \\ Takeyuki Ohtawa, Hikaru Izawa, Hideaki Sobue, \\ Rikuro Taira, Hironobu Umezawa, Xiao-Pen LeE \\ and Keizo SATO
}

\begin{abstract}
Methemoglobin (Met-Hb) is very unstable and, during the storage of blood samples, Met-Hb can be both formed and reduced. To prevent changes in Met-Hb concentrations in blood samples during storage, we have devised two methods, one in which samples are stored at $-30^{\circ} \mathrm{C}$ with a cryoprotectant and another in which samples are stored at $-80^{\circ} \mathrm{C}$ or $-196^{\circ} \mathrm{C}$ without any further additions. Both methods work well for samples of human blood stored for less than 30 days and prepared in vitro. In the present study, we examined the possibility of using these two methods to store samples for longer (e.g. up to 180 days) in the case of untreated, heated, or nitrite-treated human blood samples, as well as blood samples obtained from nitrite-treated and untreated rats. There was a marked increase in Met-Hb concentrations as a result of autoxidation in samples of untreated or heated human blood stored without a cryoprotectant at $-80^{\circ} \mathrm{C}$ over a period of 180 days ; however, Met$\mathrm{Hb}$ levels were relatively stable in the same sorts of samples at $-196^{\circ} \mathrm{C}$ over the same period. For all three types of human blood sample stored with a cryoprotectant, Met-Hb levels were relatively stable at $-30^{\circ} \mathrm{C}$, but even more so at $-80^{\circ} \mathrm{C}$ and $-196^{\circ} \mathrm{C}$, for 180 days. When blood samples from nitritetreated or untreated rats were stored without a cryoprotectant, marked autoxidation occurred at $-80^{\circ} \mathrm{C}$ and at $-196^{\circ} \mathrm{C}$, although the degree of autoxidation was less at the lower temperature. When blood samples from rats were stored with a cryoprotectant, Met-Hb levels were relatively stable at $-30^{\circ} \mathrm{C}$, and even more so at $-80^{\circ} \mathrm{C}$ and $-196^{\circ} \mathrm{C}$, for 90 days regardless of the initial concentration of Met-Hb in the sample. From these results, it appears that, for Met$\mathrm{Hb}$ determination, storage of human blood samples with a cryoprotectant at temperatures of $-30^{\circ} \mathrm{C}$ or lower and storage without any further additions at $-196^{\circ} \mathrm{C}$ are both suitable. However, frozen storage of blood samples from rats requires the addition of a cryoprotectant. Storage of blood samples from rats without a cryoprotectant at $-80^{\circ} \mathrm{C}$ and $-196^{\circ} \mathrm{C}$ resulted in Met- $\mathrm{Hb}$ formation by autoxidation.
\end{abstract}

Key words : autoxidation, blood storage, cryoprotectant, freezing, methemoglobin 


\section{Introduction}

It is well known that methemoglobin (Met-Hb) in the blood is rapidly reduced to hemoglobin $(\mathrm{Hb})$ by intraerythrocyte Met-Hb reductase when blood samples are stored as whole blood without freezing ${ }^{1-4)}$. Conversely, Sato et al demonstrated that Met-Hb formation occurs by autoxidation when blood samples are stored at $-20^{\circ} \mathrm{C}$ or $-30^{\circ} \mathrm{C}$ for 1 week or longer ${ }^{3.4)}$. In order to eliminate such changes in Met-Hb concentrations in blood samples during storage, Sato et al devised two methods, one in which samples are stored at $-30^{\circ} \mathrm{C}$ with a cryoprotectant ${ }^{3)}$ and another in which samples are stored at $-80^{\circ} \mathrm{C}$ or $-196^{\circ} \mathrm{C}$ without any further additions ${ }^{4}$. . Both methods prevent not only the reduction of $\mathrm{Met}-\mathrm{Hb}$ by $\mathrm{Met}-\mathrm{Hb}$ reductase, but also the production of Met-Hb by autoxidation during storage of blood samples over a period of 30 days $^{3.4)}$. However, the blood samples in these studies were prepared in vitro, by heating or by the direct addition of nitrites, and it is possible that Met-Hb formed in vivo will not be as stable during storage using either of these two methods. Moreover, Met-Hb formation by autoxidation may occur during periods of storage longer than 30 days, even under the storage conditions devised by Sato et al.

In the present study, we examined the possibility of using these two methods to store blood for longer (e.g. up to 180 days) in the case of human blood samples prepared in vitro, as well as the effectiveness of the two methods for storing blood samples obtained from nitrite-treated rats.

\section{Materials and Methods}

\section{Human blood samples prepared in vitro}

Human heparinized blood was collected from two healthy adult volunteers, both of whom had provided informed consent. Blood samples were assayed as soon as possible and Met- $\mathrm{Hb}$ concentrations in the samples were less than $1 \%$. For the preparation of blood samples containing high concentrations of Met- $\mathrm{Hb}$, sodium nitrite was added to erythrocytes at a ratio of $2 \mathrm{~mol} \mathrm{Hb}$ iron to $1 \mathrm{~mol}$ nitrite. This mixture was allowed to stand for $5 \mathrm{~min}$ at room temperature. Then, erythrocytes were washed four times with an adequate volume of chilled normal saline. Washed cells were mixed with plasma and used as nitrite-treated blood. For the preparation of heated blood, whole blood was heated for $15 \mathrm{~min}$ at $60^{\circ} \mathrm{C}$. This procedure resulted in the formation of a small amount of Met-Hb. To prevent further oxidation of $\mathrm{Hb}$, blood was cooled immediately in an ice bath.

\section{Blood samples from nitrite-treated rats}

Male Wistar rats, weighing 250-300 g, were fed standard laboratory chow and water ad libitum. Experimental protocols were approved by the Animal Research Committee of Showa University and were in accordance with Japanese Government Law No. 105 for the care and use of laboratory animals (approval no. 07013). All efforts were made to minimize the number of animals used and their suffering. Normal saline containing $0.25,0.50$ or $0.75 \mathrm{~g}$ sodium nitrite $/ 100 \mathrm{~mL}$ was prepared and injected intraperitoneally into rats so that they received 25,50 or $75 \mathrm{mg}$ of the oxidant $/ \mathrm{kg}$ body weight, respectively. After $1 \mathrm{~h}$, blood was collected from the heart of pentobarbiturate-anesthetized rats into a heparinized syringe. As a control, blood was collected in the same way from a rat that had not been injected with anything. 
Four rats were used in total: one control rat and one rat each injected with 25,50 or $75 \mathrm{mg} / \mathrm{kg}$ sodium nitrite.

\section{Met-Hb determination}

Blood was first diluted and hemolyzed with 30 volumes of distilled water chilled in an ice bath. After the addition of 20 volumes of $0.1 \mathrm{M}$ chilled phosphate buffer ( $\mathrm{pH} 6.8$ ), the hemolysate was centrifuged in a refrigerated centrifuge at $4000 \mathrm{~g}$ for $5 \mathrm{~min}$ at $0^{\circ} \mathrm{C}-2^{\circ} \mathrm{C}$. The clear supernatant obtained was kept in an ice bath until determination of Met-Hb concentrations. The $\mathrm{pH}$ of the supernatant was approximately 6.9 at $20^{\circ} \mathrm{C}$. Met-Hb was determined spectrophotometrically, as reported previously ${ }^{5)}$, using a Shimadzu UV-1650PC spectrophotometer (Shimadzu, Kyoto, Japan). The coefficient of variation for the method was $1.2 \%$ at a mean value of $5.09 \%{ }^{4)}$. The ambient temperature was maintained at $20^{\circ} \mathrm{C}-$ $22^{\circ} \mathrm{C}$.

\section{Cryoprotectant}

In the present study, we used the cryoprotectant solution described by Rowe et $a l^{6)}$, which contained $28 \%$ glycerol, $3 \%$ mannitol, and $0.65 \%$ sodium chloride.

\section{Storage experiments}

Two series of storage experiments were performed: (1) storage up to 180 days using human blood prepared in vitro; and (2) storage up to 90 days using blood from nitritetreated and control rats. In both series of experiments, blood was stored at $4^{\circ} \mathrm{C}$ (refrigerator), $-30^{\circ} \mathrm{C}$ (freezer), $-80^{\circ} \mathrm{C}$ (deep freezer), and $-196^{\circ} \mathrm{C}$ (liquid nitrogen container). The deep freezer used in the present study was a Sanyo MDF-192 $(750 \times 700 \times 945 \mathrm{~mm}) 86-\mathrm{L}$ freezer suitable for personal use (Sanyo, Tokyo, Japan).

In experiments investigating the storage of human untreated, heated, and nitrite-treated blood, whole blood, without any additions, was stored at $4^{\circ} \mathrm{C}$ for 7 days, as well as at $-30^{\circ} \mathrm{C},-80^{\circ} \mathrm{C}$, and $-196^{\circ} \mathrm{C}$ for up to 180 days. Simultaneously, samples of untreated, heated, and nitrite-treated blood were mixed well with an equal volume of the cryoprotectant solution described by Rowe et $a l^{6)}$ and stored at $-30^{\circ} \mathrm{C},-80^{\circ} \mathrm{C}$, and $-196^{\circ} \mathrm{C}$ for up to 180 days. To avoid the repeated freezing and thawing of human blood samples, whole blood and blood-cryoprotectant mixtures were divided into four aliquots, frozen immediately on powdered dry ice, and stored at the appropriate temperature. Then, prior to determination of Met-Hb concentrations, samples were thawed rapidly under running water, chilled immediately, and kept in an ice bath until analysis. Met-Hb concentrations were determined in blood samples at the time of storage and after 7, 30, 90, and 180 days storage.

To investigate storage of blood samples from rats, whole blood without any additions was stored at $4^{\circ} \mathrm{C}$ for 7 days, as well as at $-30^{\circ} \mathrm{C},-80^{\circ} \mathrm{C}$, and $-196^{\circ} \mathrm{C}$ for up to 90 days. In addition, blood samples from the same rats were mixed well with an equal volume of cryoprotectant ${ }^{6)}$ and the mixtures were stored at $-30^{\circ} \mathrm{C},-80^{\circ} \mathrm{C}$, and $-196^{\circ} \mathrm{C}$ for up to 90 days All blood samples (i.e. whole blood and cryoprotectant-blood mixtures) were divided into two aliquots, which were frozen immediately on powdered dry ice prior to storage. Because $\mathrm{Met}-\mathrm{Hb}$ in rat blood samples is easily reduced by Met-Hb reductase ${ }^{1-4)}$, care was taken to avoid variation among the samples during the sampling procedures. Met- $\mathrm{Hb}$ in the samples was determined as described above at the time of storage and then again after 30 and 90 
Table 1. Changes in methemoglobin concentrations in human blood samples prepared in vitro during storage under various conditions

\begin{tabular}{|c|c|c|c|c|c|c|c|c|}
\hline \multirow{3}{*}{$\begin{array}{l}\text { Blood } \\
\text { samples }\end{array}$} & \multirow{3}{*}{$\begin{array}{l}\text { Storage } \\
\text { times } \\
\text { (days) }\end{array}$} & \multicolumn{7}{|c|}{ Met-Hb (\%) } \\
\hline & & \multicolumn{4}{|c|}{ Without cryoprotectant } & \multicolumn{3}{|c|}{ With cryoprotectant } \\
\hline & & $4^{\circ} \mathrm{C}$ & $-30^{\circ} \mathrm{C}$ & $-80^{\circ} \mathrm{C}$ & $-196^{\circ} \mathrm{C}$ & $-30^{\circ} \mathrm{C}$ & $-80^{\circ} \mathrm{C}$ & $-196^{\circ} \mathrm{C}$ \\
\hline Untreated & 0 & 0.4 & 0.4 & 0.4 & 0.4 & 0.4 & 0.4 & 0.4 \\
\hline \multirow[t]{4}{*}{ blood } & 7 & 0.3 & 19.2 & 2.4 & 0.5 & 0.5 & 0.4 & 0.4 \\
\hline & 30 & - & 27.9 & 5.4 & 0.5 & 0.5 & 0.3 & 0.4 \\
\hline & 90 & - & 38.3 & 11.4 & 0.6 & 0.6 & 0.4 & 0.3 \\
\hline & 180 & - & 40.8 & 13.4 & 0.8 & 0.7 & 0.5 & 0.4 \\
\hline \multirow[t]{5}{*}{ Heated blood } & 0 & 5.8 & 5.8 & 5.8 & 5.8 & 5.8 & 5.8 & 5.8 \\
\hline & 7 & 6.2 & 21.7 & 6.9 & 5.9 & 5.8 & 5.8 & 5.8 \\
\hline & 30 & - & 27.7 & 8.7 & 5.9 & 5.7 & 5.7 & 5.8 \\
\hline & 90 & - & 32.0 & 12.6 & 6.1 & 5.8 & 5.8 & 5.9 \\
\hline & 180 & - & 36.7 & 17.0 & 6.2 & 5.9 & 5.9 & 5.8 \\
\hline Nitrite- & 0 & 44.6 & 44.6 & 44.6 & 44.6 & 44.6 & 44.6 & 44.6 \\
\hline \multirow[t]{4}{*}{ treated blood } & 7 & 4.3 & 47.5 & 45.7 & 45.6 & 44.5 & 44.6 & 44.6 \\
\hline & 30 & - & 48.1 & 46.0 & 45.8 & 44.7 & 44.6 & 44.6 \\
\hline & 90 & - & 49.2 & 46.1 & 45.9 & 44.8 & 44.7 & 44.7 \\
\hline & 180 & - & 52.3 & 46.2 & 46.0 & 44.9 & 44.8 & 44.7 \\
\hline
\end{tabular}

Values are the average of results obtained for blood samples from two human volunteers. Met-Hb, methemoglobin ; -, no determination was made.

days storage. In the present study, for samples stored with cryoprotectant solution, Met-Hb was determined without the prior removal of the cryoprotectant because preliminary experiments indicated that the presence of the cryoprotectant had no effect on Met-Hb concentrations.

\section{Results}

\section{Storage of human blood prepared in vitro}

When nitrite-treated whole blood was stored without any additions, there was a marked reduction in Met-Hb concentrations at $4^{\circ} \mathrm{C}$ over a period of 7 days, whereas at $-30^{\circ} \mathrm{C}$ a slight increase in Met-Hb concentrations was observed as a result of autoxidation (Table 1). Storing untreated or heated whole blood without cryoprotectant for 180 days resulted in marked autoxidation of Met-Hb at both $-30^{\circ} \mathrm{C}$ and $-80^{\circ} \mathrm{C}$. However, at $-196^{\circ} \mathrm{C}$, Met-Hb levels were relatively stable in both untreated and heated whole blood over the same time period. When human blood was stored in the presence of cryoprotectant, Met-Hb levels were relatively stable at $-30^{\circ} \mathrm{C}$, and even more so at $-80^{\circ} \mathrm{C}$ and $-196^{\circ} \mathrm{C}$, for at 180 days, regardless of the initial concentration of Met-Hb in the samples (Table 1).

\section{Storage of blood samples from nitrite-treated rats}

When blood samples from rats were stored at $4^{\circ} \mathrm{C}$, there was a marked reduction in Met$\mathrm{Hb}$ concentrations in nitrite-treated rats, whereas in the single control rat that was not treat- 
Table 2. Changes in methemoglobin concentrations in blood samples from nitrite-treated rats during storage under various conditions

\begin{tabular}{|c|c|c|c|c|c|c|c|c|}
\hline \multirow{3}{*}{$\begin{array}{l}\text { Nitrite } \\
(\mathrm{mg} / \mathrm{kg})\end{array}$} & \multirow{3}{*}{$\begin{array}{l}\text { Storage } \\
\text { times } \\
\text { (days) }\end{array}$} & \multicolumn{7}{|c|}{ Met-Hb (\%) } \\
\hline & & \multicolumn{4}{|c|}{ Without cryoprotectant } & \multicolumn{3}{|c|}{ With cryoprotectant } \\
\hline & & $4^{\circ} \mathrm{C}$ & $-30^{\circ} \mathrm{C}$ & $-80^{\circ} \mathrm{C}$ & $-196^{\circ} \mathrm{C}$ & $-30^{\circ} \mathrm{C}$ & $-80^{\circ} \mathrm{C}$ & $-196^{\circ} \mathrm{C}$ \\
\hline \multirow[t]{4}{*}{0} & 0 & 0.4 & 0.4 & 0.4 & 0.4 & 0.4 & 0.4 & 0.4 \\
\hline & 7 & 0.5 & - & - & - & - & - & - \\
\hline & 30 & - & 22.7 & 5.7 & 2.2 & 0.6 & 0.4 & 0.4 \\
\hline & 90 & - & 32.4 & 7.1 & 2.9 & 0.8 & 0.6 & 0.4 \\
\hline \multirow[t]{4}{*}{25} & 0 & 3.5 & 3.5 & 3.5 & 3.5 & 3.5 & 3.5 & 3.5 \\
\hline & 7 & 0.5 & - & - & - & - & - & - \\
\hline & 30 & - & 25.2 & 7.0 & 4.6 & 3.7 & 3.6 & 3.6 \\
\hline & 90 & - & 34.6 & 10.1 & 5.1 & 3.8 & 3.7 & 3.6 \\
\hline \multirow[t]{4}{*}{50} & 0 & 23.8 & 23.8 & 23.8 & 23.8 & 23.8 & 23.8 & 23.8 \\
\hline & 7 & 1.0 & - & - & - & - & - & - \\
\hline & 30 & - & 31.9 & 28.1 & 25.9 & 23.9 & 23.8 & 23.8 \\
\hline & 90 & - & 43.0 & 32.1 & 27.9 & 24.1 & 24.0 & 23.9 \\
\hline \multirow[t]{4}{*}{75} & 0 & 74.6 & 74.6 & 74.6 & 74.6 & 74.6 & 74.6 & 74.6 \\
\hline & 7 & 2.5 & - & - & - & - & - & - \\
\hline & 30 & - & 84.1 & 76.7 & 76.5 & 74.7 & 74.7 & 74.6 \\
\hline & 90 & - & 84.5 & 79.7 & 77.2 & 75.2 & 74.8 & 74.5 \\
\hline
\end{tabular}

Values are results from blood samples obtained from one rat in each group.

Met-Hb, methemoglobin ; -, no determination was made.

ed with nitrite, the initial low concentration of Met-Hb was stable over a period of 7 days (Table 2). When blood samples from rats were stored in the absence of cryoprotectant, marked autoxidation occurred at $-80^{\circ} \mathrm{C}$ and $-30^{\circ} \mathrm{C}$. At $-196^{\circ} \mathrm{C}$, autoxidation of $\mathrm{Hb}$ still occurred, although to a lesser degree than that seen in samples stored at higher temperatures. When blood samples from rats were stored in the presence of a cryoprotectant, Met$\mathrm{Hb}$ levels were relatively stable at $-30^{\circ} \mathrm{C}$, and even more so at $-80^{\circ} \mathrm{C}$ and $-196^{\circ} \mathrm{C}$, over a period of 90 days, regardless of the initial concentration of Met-Hb in the sample (Table 2).

\section{Discussion}

The results of the present study indicate that autoxidation of $\mathrm{Hb}$ occurs even in frozen blood samples stored at $-30^{\circ} \mathrm{C}$ or $-80^{\circ} \mathrm{C}$ and that the addition of a cryoprotectant solution to whole blood prevents $\mathrm{Hb}$ autoxidation (Tables 1,2). The results of the present study indicate that storage of blood samples from nitrite-treated or untreated rats with a cryoprotectant, as described previously ${ }^{3)}$, works well for at least 90 days (Table 2). It should be noted that Met-Hb formation by autoxidation was observed in samples of human blood stored without a cryoprotectant at $-80^{\circ} \mathrm{C}$, as well as in blood samples from rats stored without cryoprotectant at $-196^{\circ} \mathrm{C}$. However, we have reported previously ${ }^{4,7)}$ that human blood samples can be stored at $-80^{\circ} \mathrm{C}$ without significant changes in Met- $\mathrm{Hb}$ concentrations 
for 30 or 60 days. We suspect that the differences between the studies may be related to the deep freezers used to store the blood samples. When we conducted our earlier studies, the deep freezer we used was a large unit, suitable for laboratory use, with temperatures generally of $-84^{\circ} \mathrm{C}$, even though we described them as $-80^{\circ} \mathrm{C}$ in the papers ${ }^{4.7)}$. Thus, in the previous studies, we assume that samples were stored at $-80^{\circ} \mathrm{C}$. Conversely, during the course of the present study we used a smaller deep freezer, suitable for personal use, that was used by the entire laboratory. This meant that the freezer was often opened and, thus, it is possible that the blood samples were exposed to temperatures greater than $-80^{\circ} \mathrm{C}$ during the period of storage. It is known that $\mathrm{Hb}$-bound water is frozen at $-80^{\circ} \mathrm{C}^{6)}$. We believe that the $\mathrm{Hb}$-bound water was frozen in our previous studies ${ }^{4.7)}$, which resulted in stable values of Met-Hb over 30 and 60 days. However, in the present study, it is possible that the $\mathrm{Hb}$-bound water was not always frozen, resulting in marked autoxidation of $\mathrm{Hb}$. In any case, storage of whole blood at $-80^{\circ} \mathrm{C}$ in a small deep freezer is not suitable when carboxyhemoglobin $(\mathrm{COHb})$ is to be determined by methods in which blood samples are saturated with carbon monoxide $(\mathrm{CO})$ as an internal standerd ${ }^{89}{ }^{8)}$ because Met-Hb formed during storage is unable to bind $\mathrm{CO}$. Instead, $\mathrm{COHb}$ in frozen blood samples should be evaluated using methods that are suitable for blood containing Met- $\mathrm{Hb}^{10,11}$.

Because the precise mechanism by which autoxidation of $\mathrm{Hb}$ in the frozen state occurs is not yet known, future studies are needed to clarify this interesting phenomenon. At present, we can only say that modification of the structure of $\mathrm{Hb}$ in the frozen state at $-30^{\circ} \mathrm{C}$ or $-80^{\circ} \mathrm{C}$ may have resulted in oxidation of $\mathrm{Hb}$ iron in the unfrozen Hb-bound water ${ }^{6}$ and that this oxidation was considerably inhibited by the addition of a cryoprotectant to samples stored at $-30^{\circ} \mathrm{C}$ or $-80^{\circ} \mathrm{C}$ or by storage at $-196^{\circ} \mathrm{C}$. Furthermore, modification of the structure of $\mathrm{Hb}$ in the frozen state seems to be more marked in blood from rats than humans because, in the present study, slight autoxidation was observed in blood samples from rats, but not humans, stored at $-196^{\circ} \mathrm{C}$ without a cryoprotectant (Table 2).

The results of the present study, using blood samples from two human volunteers, indicate that human blood can be stored, without marked changes in Met-Hb concentrations over a period of 180 days, in either the presence of a cryoprotectant at temperatures of $-30^{\circ} \mathrm{C}$ or lower or without any additions at $-196^{\circ} \mathrm{C}$. It should be noted that the frozen storage of blood samples from rats requires the addition of a cryoprotectant; it appears that Met$\mathrm{Hb}$ formation by autoxidation may occur during the storage of blood samples from humans stored without a cryoprotectant even at a temperature of $-80^{\circ} \mathrm{C}$.

\section{References}

1) Sleight SD and Sinha DP: Prevention of methemoglobin reduction in blood samples. J Am Vet Med Assoc 152 : 1521-1525 (1968)

2) Fukui $Y$, Yamamoto $Y$ and Matsubara $K$ : Reduction with the lapse of time of methemoglobin in blood sample. Jpn J Legal Med 34 : 563-568 (1980)

3) Sato K, Katsumata Y, Aoki M, Tamaki K and Yada S: Long-term storage of blood samples at freezing temperatures in the presence of a cryoprotectant for hemiglobin assay. Biochem Med Metab Biol 37: 190-196 (1987)

4) Sato K, Tamaki K, Okajima $\mathrm{H}$ and Katsumata $\mathrm{Y}$ : Long-term storage of blood samples as whole blood at extremely low temperatures for methemoglobin determination. Forensic Sci Int 37 : 99-104 (1988)

5) Sato K, Katsumata Y, Aoki M, Oya M and Yada S: A practical method for the accurate determination of methemoglobin in blood containing carboxyhemoglobin. Forensic Sci Int 17 : 177-184 (1981)

6) Rowe AW, Eyster $\mathrm{E}$ and Kellner $\mathrm{A}$ : Liquid nitrogen preservation of red blood cells for transfusion: a low glycerol-rapid freeze procedure. Cryobiology $5: 119-128$ (1968) 
7) Sato K, Tamaki K, Hattori H, Moore CM, Tsutsumi H, Okajima H and Katsumata Y: Determination of total hemoglobin in forensic blood samples with special reference to carboxyhemoglobin analysis. Forensic Sci Int 48 : 89-96 (1990)

8) Hessel DW and Modglin FR: The determination of carbon monoxide in blood by gas-solid chromatography. $J$ Forensic Sci 12 : 123-131 (1967)

9) Dominguez AM, Christensen HE, Goldbaum LR and Stembridge VA : A sensitive procedure for determining carbon monoxide in blood and tissue utilizing gas-solid chromatography. Toxicol Appl Pharmacol 1: 135-143 (1959)

10) Katsumata Y, Aoki M, Sato K, Suzuki O, Oya M and Yada S : A simple spectrophotometry for determination of carboxyhemoglobin in blood. J Forensic Sci 27 : 928-934 (1982)

11) Katsumata $Y$, Sato $\mathrm{K}$ and Yada $\mathrm{S}$ : A simple and high-sensitive method for determination of carbon monoxide in blood by gas chromatography. Acta Crim Jpn 51 : 139-144 (1985)

[Received January 23, 2008 : Accepted February 8, 2008] 